mental Station and the Macaulay Institute for Soil Research. The Nature Conservancy, which is concerned with woodlands, has also been of great assistance. In order to secure liaison in fields of common interest, a small informal committee of representatives of the Nature Conservancy and the Forestry Commission has been established to discuss matters of research and investigation. The Research Branch of the Commission also takes an active part in the affairs of the International Union of Forest Research Organizations.

\section{Rhizomorph Behaviour in Armillaria}

S. D. GARRETT has investigated some of the factors which determine the vigour of the infection of potato tubers by the rhizomorphs of Armillaria mellea (Ann. Bot., N.S., 20, 78, 194 ; 1956). The growth of rhizomorphs of Armillaria mellea from small woody inocula through tubes of soil was characterized by a progressive decline in weekly growth increments. The initial growth-rate was related to the size of the inoculum food-base; the subsequent decline is attributed partly to depletion of nutrient reserves in the inoculum through fungal respiration and growth, and partly to competition for nutrients between the main growing apex of the rhizomorph and its subordinate branch apices. The vigour of infection of potato tubers by rhizomorphs from such small woody inocula increased with size of the inoculum, and decreased with increasing distance between inoculum and tuber. When the inoculum potential of $A$. mellea was low, the fungus was generally overtaken in the tuber tissues by soft-rotting bacteria, which prevented its further advance.

\section{Zoological Nomenclature}

As from November 9, 1956, the International Commission on Zoological Nomenclature will start to vote on the following cases involving the possible use of its plenary powers for the purposes specified against each entry. Full details have already been published. (Bull. Zool. Nom., 11, Pt. 11, 1956). (1) Turbinella Lamarck, 1799 (Cl. Pelecypoda), validation ; (2) Terrakea Booker (F. W.), 1930, designation of type species for, and brachythaerus Morris, 1845 (Productus), validation of (Cl. Brachiopoda) ; (3) Unio Philipsson, 1788 (Cl. Pelecypoda), designation of type species for ; (4) Elaphe Fitzinger, 1833 (Cl. Reptilia), validation; (5) daea Dampf, 1910 (Palaeopsylla) (Cl. Insecta), determination; (6) Torquesia Douvillé, 1929 (Cl. Gastropoda), designation of type species for ; (7) Horniman (R. B.), January 1940, "Preliminary Descriptions of some new Birds", suppression. Comments should be sent as soon as possible to the secretary to the Commission, Mr. Francis Hemming, 28 Park Village East, Regent's Park, London, N.W.I.

\section{Equal-Loudness Contours for Pure Tones}

THe equal-loudness contours for pure tones heard binaurally have been redetermined at the Acoustics Section of the National Physical Laboratory, Teddington, by D. W. Robinson and R. S. Dadson (Brit. J. App. Phys., 7, 166; May 1956). Loudness is one of the few concepts which can be correlated with several aspects of the complicated subjective reaction to a sound and therefore provides a starting-point for measurement in such work. The relation between the loudness of a sound and its root-mean-square pressure and frequency for various waveforms and for binaural and monaural hearing is of interest not only in the understanding of the hearing mechanism and its reaction to pure and complex sounds, but also in the design of frequency-weighting circuits for such instruments as the 'sound-level meter' and in the calculation of loudness-levels from the spectrum analysis of sounds. Discrepancies exist between the previously published pure tone equal-loudness contours for free-field conditions (Fletcher, H., and Munson, W. A., J. Acous. Soc. Amer., 5, 82 (1933), and Churcher, B. G., and King, A. J., J. Inst. Elec. Eng., 81, 57 (1937) ), and it was not possible to derive an acceptable standard. The new work reported by the National Physical Laboratory, which covers increased ranges of frequency and sound pressure and the effect of age and sex of otologically normal subjects, is a welcome redetermination. Although these results differ by up to 10 phons from the previous determinations, they are more regular with sound pressure and frequency, and the errors are estimated to be only about \pm 1 phon over the greater part of the work.

\section{Royal Commission for the Exhibition of 1851 : Awards for 1955}

The Royal Commission for the Exhibition of 1851 has awarded the following senior studentships for 1956 for research at the universities indicated: C. M. P. Johnson (Cambridge), nuclear physics at Cambridge; C. B. Reese (Cambridge), organic chemistry at Cambridge; Dr. M. W. Windsor (Cambridge), physical chemistry at Sheffield; A. J. Smith (Wales), geology at the University College of Wales, Aberystwyth. The Commission has also awarded the following overseas scholarships for 1956 : Canada: C. B. M. Bailey (British Columbia), animal growth; C. Crowe (Western Ontario), physics at Cambridge. Australia: Dr. (Miss) B. I. H. Hall (Adelaide), physics at University College, London; A. L. Hunt (Adelaide), biochemistry at Oxford; S. P. H. Mandel (Sydney), mathematics at Cambridge; D. A. Levy (Sydney), theoretical chemistry at Cambridge. New Zealand: G. G. Pritchard (New Zealand), botany at Cambridge; W. D. Twose (New Zealand), physics at Cambridge. India: Dr. J. Jacob (Annamalai), zoology at Queen's College, Dundee, University of St. Andrews. Pakistan: F. Aziz (Lahore), radiochemistry at Cambridge.

\section{University of Nottingham : Gifts}

THE following gifts have been received by the University of Nottingham: $\$ 2,000$ a year for fire years from Imperial Chemical Industries, Ltd., towards the cost of building up a school of colloid science in the Physical Chemistry Laboratory; a research scholarship of $£ 600$ a year from $W$. Canning and Co., Ltd., of Birmingham, to be held in the Department of Metallurgy, for research in the field of metal finishing; $£ 300$ a year for three years from the Electro-Chemical Engineering Co., Ltd., of Woking, to the Department of Metallurgy towards the cost of a scholarship for research in metal finishing.

\section{Physics of Nuclear Reactors}

A CONFERENCE on "The Physics of Nuclear Reactors" arranged by the Institute of Physics was held in the Institution of Electrical Engineers during July $3-6$. The programme opened with an address by Sir John Cockeroft, president of the Institute, on "Scientific Problems in the Development of Nuclear 